\title{
WYCHOWANIE DO EMPATII JAKO SPOSÓB NA REDUKCJĘ STRESU I JEGO SZKODLIWYCH SKUTKÓW U DZIECI I MLODZIEŻY
}

Streszczenie: W tekście zaprezentowano interdyscyplinarne ujęcie wychowania do empatii, oparte na autorskim modelu teoretycznym. Przyjęcie tak rozumianej definicji empatii skutkuje wszechstronnym i wielopoziomowym oddziaływaniem na dzieci i młodzież. Efekty tych działań przynoszą różnorodne korzyści na poziomie wewnątrzosobowym oraz interpersonalnym - w tym wpływają na redukcję poziomu stresu u dzieci oraz wzmocnienie zasobów osobowościowych i społecznych przyczyniających się do polepszenia strategii radzenia sobie ze stresem i jego negatywnymi skutkami. Empatia jest także sprawdzoną metodą profilaktyki dotyczącej przemocy rówieśniczej - ciągle aktualnego problemu w polskiej szkole, prowadzącego do licznych strat zdrowotnych.

Słowa kluczowe: empatia, zdrowie, stres, samoregulacja emocjonalna, przemoc rówieśnicza, dzieci, młodzież.

Analizując wyniki badań nad chorobami stanowiącymi zagrożenie dla życia ludzi w Polsce, do najważniejszych należy zaliczyć choroby układu krążenia oraz nowotworowe. Zaliczane są one do chorób cywilizacyjnych i w dużej mierze wiążą się ze stylem życia (Dziubak i in. 2011).

Jednym z czterech najważniejszych czynników wpływających na stan zdrowia współczesnych młodych Polaków jest stres (Kolarczyk 2015). Zmniejszanie jego poziomu oraz rozwijanie u dzieci umiejętności radzenia sobie z wyzwaniami życia codziennego jest zatem ważnym zadaniem edukacji prozdrowotnej. Jak wskazują badania, grupą szczególnie narażoną na stres są adolescenci, np. badania Czerwiak z zespołem (2012) wykazały, że znaczna część młodzieży gimnazjalnej nie potrafi skutecznie radzić sobie ze stresem - 48 proc. dziewcząt i 41 proc. chłopców tłumi lub kumuluje w sobie negatywne emocje. Działania prewencyjne należy jednak podjąć odpowiednio wcześnie, edukując dzieci już na pierwszych etapach nauki. Wyzwaniem pozostaje nie tylko rozwijanie u dzieci skutecznych strategii radzenia sobie ze stresem, ale także tworzenie wspierającego środowiska szkolnego, oraz 
minimalizowanie czynników stresogennych (Czerwiak i in. 2012). Przyjazne, wpierające środowisko wychowawcze, to w znacznej mierze grupa wolna od przemocy rówieśniczej, która stanowi ciągle zjawisko dość powszechne i sama w sobie jest zagrożeniem dla zdrowia dzieci (Włodarczyk 2013).

Wychowanie do empatii może być sposobem zarówno na radzenie sobie z problemem przemocy, jak i na skuteczną profilaktykę stresu, i wypracowanie skutecznych metod radzenia sobie z jego negatywnymi skutkami. Dzieje się tak dlatego, że poprzez wprowadzanie programów rozwijających empatię oddziałujemy na szereg czynników osobowościowych (np. samoświadomość emocjonalną, samoregulację, podejmowanie decyzji, wyobraźnię) oraz środowiskowych (zmniejszenie przemocy rówieśniczej i agresji, zwiększenie działań prospołecznych, współpracy, wsparcia społecznego). Dla dokładnego zrozumienia, jak metody wychowania do empatii przekładają się na sygnalizowane korzyści, warto przybliżyć w pierwszej kolejności przyjętą na potrzeby niniejszej pracy definicję empatii, wynikającą z jej ujęcia w modelu poznawczo-emocjonalnym uwzględniającym jej epizodyczno-kontekstowy charakter.

\section{Model empatii}

Empatia definiowana jest jako zdolność rozumienia i wczuwania się w stany innych osób (por. Davis 1983; Cohen, Strayer 1996). Zawiera zatem zdolność zarówno poznawczego „rozumienia”, co myśli i czuje druga osoba (czynnik poznawczy), jak i emocjonalną zdolność współodczuwania (czynnik afektywny), czyli podzielania afektów innych ludzi. Niektórzy badacze zwracają także uwagę na czynnik behawioralny, związany z działaniami na rzecz innych (komunikowanie empatii, empatyczne działania).

Wielu badaczy (por. Enz i in. 2009) opiera się na tworzeniu teoretyczno-empirycznych modeli empatii. Coraz dokładniejsze modele teoretyczne empatii oraz metody badawcze dostarczają nowych danych na temat natury tej cechy i jej korelat. Wiedza ta ma swoje praktyczne zastosowanie - dzięki niej poznajemy mechanizmy działania empatii, przyczyny jej obniżonego poziomu u niektórych osób, oraz skuteczne metody jej rozwijania u osób w każdym wieku. Jest to podejście użyteczne nie tylko ze względu na badawcze korzyści, lecz także praktyczne implikacje. Integrując wiedzę na temat empatii z różnych dziedzin i umieszczając ją w modelu, otrzymujemy wytyczne, na które czynniki warto oddziaływać, planując przedsięwzięcia edukacyjne i wychowawcze. Poniżej przedstawiony jest autorski model empatii, będący także podstawą opracowania programu rozwoju empatii skierowanego do dzieci w wieku 9-11 lat, realizowanego w ramach własnego projektu badawczego autora artykułu w latach 2012-2015. Rysunek 1 zestawia ze sobą czynniki wpływające na poziom empatii w jego dynamice epizodycznej i rozwojowej - własny model empatycznej reakcji. 
Rys. 1.

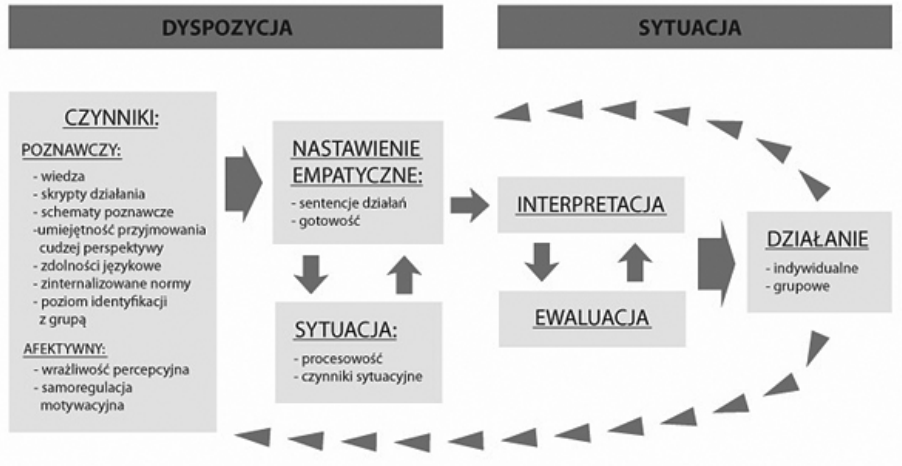

PERSPEKTYWA ROZWOJOWA WIEKU 10-11 LAT I JEJ KONTEKSTY KULTUROWO-SPOLECZNE

Źródło: opracowanie własne.

Bazując na tak przygotowanym modelu, możemy przyjąć, że o sile i jakości empatycznej reakcji decydują różne czynniki dyspozycyjne (osobowościowe) i sytuacyjne. Czynniki osobowościowe możemy podzielić na poznawcze i afektywne. Do czynników poznawczych zaliczamy wiedzę na temat emocji, znajomość ich nazw, umiejętność rozpoznawania, identyfikowania własnych i cudzych stanów emocjonalnych (np. na podstawie ekspresji emocjonalnej werbalnej i niewerbalnej), a także zdolność przyjmowania cudzej perspektywy, czy wypracowanie odpowiednich skryptów poznawczych związanych z konkretnymi sytuacjami (np. pomaganie innym, konflikt itp.) opartych na zinternalizowanych normach indywidualnych i grupowych. Czynniki te są niezbędnymi predyspozycjami osobowościowymi, koniecznymi do zainicjowania empatycznej reakcji oraz odpowiedniej interpretacji własnych i cudzych reakcji.

Kolejnym czynnikiem są emocjonalne procesy związane z reaktywnością i wrażliwością. Bazując na neurologicznych strukturach, m.in. na tzw. „neuronach lustrzanych”, opisanych po raz pierwszy przez Rizolatti (1996), każdy człowiek jest zdolny do współodczuwania. Obecne badania wskazują na złożoność afektywnej reakcji, uzależnionej od zaangażowania wielu struktur, oraz mówią, że sama wrażliwość emocjonalna nie wystarczy do osiągnięcia pełni empatycznych zdolności. Dodatkowymi elementami sprzyjającymi czy też umożliwiającymi pełną empatyczną reakcję jest także zdolność samoregulacji emocjonalnej oraz emocjonalna samoświadomość. Sama wrażliwość emocjonalna może bowiem prowadzić do różnych, niekoniecznie korzystnych i empatycznych reakcji afektywnych. Przykładowo, osoba bardzo wrażliwa, widząc czyjeś cierpienie, może zostać „przestymulowana”, w wyniku czego może zareagować złością lub wycofaniem, jeśli nie będzie posiadała wyuczonych mechanizmów regulacji własnego pobudzenia emocjonalnego. Aby umożliwić empatyczną reakcję, konieczna jest zdolność do odróżniania własnych emocji od współodczuwanych emocji drugiej osoby, a także inteligentne zarządzanie własnymi stanami, będącymi reakcją afektywną na stany innych osób (Goleman 2007). 
Kolejną grupą czynników są czynniki wypływające z procesualnego charakteru empatii. Empatia w ujęciu epizodyczno-procesualnym (Lawrence $i$ in. 2004) zakłada, że reakcje emocjonalno-poznawcze następują kolejno po sobie i od ich jakości zależy efekt mający charakter komunikacyjny. Etapy tak rozumianej reakcji możemy podzielić na: zauważenie sygnałów emocjonalnych, uruchomienie procesów afektywnych i poznawczych, wytworzenie empatycznego nastawienia i sformułowanie empatycznej odpowiedzi, reakcji. Z punktu widzenia praktyki rozwijania empatii konieczne jest wdrażanie metod, które ćwiczą zarówno poszczególne elementy procesu, jak i jego całościowy przebieg. Warto zwrócić uwagę na znaczenie procesu komunikacji, interakcji pomiędzy uczestnikami empatycznego epizodu. Umiejętności społeczne (szczególnie komunikacyjne) są ważnym elementem włączanym przez niektórych badaczy do modelu empatii (por. Baron-Cohen 2014)

Niezwykle ważne jest także otoczenie, w jakim odbywa się cały proces współodczuwania - tutaj wpływ mają czynniki sytuacyjne, szczególnie normy grupowe $\mathrm{i}$ indywidualne, zasady panujące $\mathrm{w}$ grupie czy też instytucji, dostępne procedury, mechanizmy wsparcia. Zdolności empatyczne uzależnione są także od wieku (por. Davis 1999; Hoffman 2006).

Przyjmując tak złożony model empatii, wychowanie do empatii powinno uwzględniać możliwie jak najszerszy zakres oddziaływań zarówno na czynniki osobowościowe, jak i sytuacyjne. Rozwijanie empatii nie powinno być traktowane jedynie jako trening umiejętności czy też odosobnione działania uwrażliwiające, ale jako tworzenie całego systemu oddziaływań, mającego na celu powstanie tzw. „kultury empatii". Tego typu oddziaływania wiążą się z różnorodnymi korzyściami, wynikającymi z wysokiego poziomu empatii.

Empatia kojarzona jest na ogół z jej dobroczynnymi skutkami: znane są liczne badania wskazujące na to, że pozytywnie wiąże się ona z działaniami prospołecznymi, współpracą, zaś jej brak wymieniany jest jako czynnik towarzyszący zachowaniom agresywnym, antyspołecznym, ale także licznym zaburzeniom psychicznym, np. zaburzeniom osobowości, anoreksji (por. Baron-Cohen 2014).

Powszechnie znane korzyści płynące z wysokiego poziomu empatii przekładają się na działania edukacyjne i profilaktyczne, szczególnie dotyczące przeciwdziałania agresji i przemocy, ale także na oddziaływania terapeutyczne w stosunku do osób wykazujących deficyty empatii (co wykorzystuje się np. w trakcie terapii zaburzeń osobowości czy zaburzeń ze spektrum autyzmu). Istnieje wiele programów mających na celu rozwijanie empatii u dzieci i dorosłych, gdyż jej pielęgnowanie przekłada się na mniej agresywne, bardziej prospołeczne nastawienie, lepsze społeczne funkcjonowanie, a co za tym idzie, na polepszenie zdrowia.

Stosunkowo rzadziej poruszanym zagadnieniem jest tworzenie „kultury empatii”, co wiąże się nie tylko z funkcjonowaniem społecznym i profilaktyką agresji oraz przemocy, lecz także sięga o wiele dalej - powiązane jest $\mathrm{z}$ dodatkowymi korzyściami, wynikającymi z budowania odporności oraz tworzenia zasobów 
osobowościowych. Empatyczne dzieci wykazują nie tylko bardziej konstruktywne wzorce relacji z innymi ludźmi, ale także posiadają szereg umiejętności, m.in. zdolność samoregulacji i samokontroli, a także samoświadomości. Umiejętności te wpływają z kolei na kształtowanie odporności psychicznej, umiejętności radzenia sobie ze stresem i jego negatywnymi konsekwencjami, podejmowanie decyzji. W dobie zagrożeń zdrowia spowodowanych zmianą trybu życia oraz w świetle badań epidemiologicznych warto zainteresować się metodami rozwijającymi empatię u dzieci, jako skuteczną pomoc w profilaktyce zdrowotnej. Jednym z pozytywnych skutków wysokiego poziomu empatii jest zmniejszenie poziomu stresu oraz sposobów radzenia sobie w trudnych sytuacjach. W kolejnej części tekstu zostaną omówione bardziej szczegółowo poszczególne wyniki badań nad korzyściami płynącymi z empatii, z rozbiciem na skutki osobowościowe (cechy i zasoby wewnętrzne) oraz środowiskowe (relacje z innymi osobami, relacje grupowe, środowisko wychowawcze).

\section{Wewnątrzosobowe czynniki empatii zmniejszające poziomu stresu oraz wspomagające radzenie sobie z jego negatywnymi skutkami}

Aby rozwijać empatię u dzieci, należy zadbać o szereg umiejętności koniecznych do tego, aby dziecko osiągnęło maksymalny zakres możliwości empatycznych. Odnosząc się do modelu empatii opisanego wcześniej, zasadne jest rozwijanie osobowościowych zasobów dziecka (np. wiedzy o emocjach, mechanizmów samokontroli) (por. Davis 1999; Hoffman 2006; Baron-Cohen 2014; Borba 2016), ale także sytuacyjnie wyzwalanych skryptów działań - poznawczo-emocjonalnych oraz czynników sytuacyjnych - procedur, norm indywidualnych i grupowych (por. Laremise, Arsenio 2000). Ponadto warto zwrócić uwagę na aspekt komunikacyjny empatycznego procesu (Lawrence i in. 2004) i włączenie do definicji empatii zdolności jej komunikowania w relacji z innymi ludźmi.

Przyjmując takie założenia dotyczące empatii, oddziaływania edukacyjne powinny być skierowane na szereg umiejętności przekładających się na odciążenie dzieci, wzmocnienie ich oraz poprawę relacji z otoczeniem.

Jednym $z$ elementów treningów empatii jest rozwijanie wiedzy na temat emocji, a także umiejętności ich rozpoznawania (por. Wilczek-Różyczka 2002; Lewicka 2006). Różnego rodzaju ćwiczenia mają zatem na celu zwiększanie wiedzy z zakresu znajomości nazw własnych emocji (np. jak nazwać to, co teraz czuję) oraz emocji innych osób (np. jak nazwać to, co może czuć w danej sytuacji inna osoba). Dzieci podczas tego typu zajęć uczą się reagować na sygnały niewerbalne i werbalne analizować i interpretować nawet subtelne komunikaty. Dodatkowo rozwijana jest wiedza o samych emocjach: dzieci uczą się, czemu służą emocje (także te trudne), jak można je wykorzystać w życiu. Dzięki takim zabiegom wzrasta ich samoświadomość emocjonalna - ważny element redukcji stresu. Dzieci mają większą świadomość, co dzieje się z nimi w różnych sytuacjach, czemu służą różne emocje, 
ich własne i innych osób. Nadawanie sensu tym procesom jest szczególnie ważne z punktu widzenia wyrabiania mechanizmów samoregulacji i inteligencji emocjonalnej (Goleman 2007). Dodatkowo, przy programach rozwoju empatii włącza się różnego rodzaju ćwiczenia technik obniżania napięcia emocjonalnego. Znajomość nazw emocji i umiejętność ich identyfikowania przydaje się dzieciom do uwalniania napięcia. Dzielenie się emocjami, werbalizowanie ich w relacji z drugą osoba (rówieśnikami, nauczycielami, rodzicami) przynosi im ulgę i pozwala poradzić sobie z trudnościami (Howe 2013).

Ćwiczenie umiejętności samoregulacji jest konieczne ze względu na naturę empatii - aby móc się empatyzować z drugą osobą, należy najpierw samemu osiągnąć stan optymalnego pobudzenia emocjonalnego. Tak zwana pułapka empatii (ang. empathy gap) to dobrze udokumentowane zjawisko psychologiczne (por. Loevenstein 2005), wskazujące na mechanizm, w którym skrajne stany pobudzenia emocjonalnego wpływają na postrzeganie cudzych emocji (np. ciężko komuś zdenerwowanemu zrozumieć osobę spokojną, a osobie spokojnej przyjąć punkt widzenia osoby wzburzonej). Dlatego właśnie wiele czasu poświęca się na ćwiczenia u dzieci technik relaksacyjnych, związanych z oddechem (np. technik mindfullnes). Wiele badań neurobiologicznych wskazuje bowiem na to, że powolne oddychanie powoduje zmniejszenie poziomu stresu (por. Siegel 2007). Jedną z technik wspomagających tego typu działania są tzw. „krzesła spokoju”, ustawione w salach klasowych. Dzieci dzieci mogą na nich usiąść i wykonać kilka ćwiczeń oddechowych w celu obniżenia napięcia (Borba 2016).

W ramach treningów i programów empatii ćwiczona jest także wyobraźnia oraz zdolność refleksji. Dzieci np. poprzez analizowanie różnego rodzaju sytuacji, dylematów moralnych uczą się przewidywania konsekwencji własnych działań zastanawiania się nad tym, jak dana decyzja moralna wiąże się z ich zasadami czy z zasadami innych osób. Mając wiele możliwości interakcji, obserwacji oraz odczucia reakcji innych osób na różnego rodzaju sytuacje, dzieci rozwijają własną wiedzę na temat konsekwencji określonych zachowań. Skłanianie dzieci do fantazjowania dotyczącego określonych sytuacji (np. wspólne zastanawianie się, jak skończy się dana historia, bajka czy film) pomaga rozwijać wyobraźnię i przewidywać reakcje poszczególnych osób. Tworzenie tzw. Teorii Umysłu (Theory of Mind) to ważna z punktu widzenia rozwoju empatii umiejętność (Bowlby 2007). Istnieje wiele ćwiczeń i zabaw pozwalających na rozwijanie tego typu zdolności. Dzieci stwarzają różnego rodzaju procedury pomagające im w podejmowaniu trudnych decyzji, np. zadają sobie kilka testowych pytań: Czy to jest zgodne z moimi normami? Czy sam chciałbym, aby ktoś mnie tak potraktował? Jak wpłynie to na ważne dla mnie osoby? Co powiedziałaby mama? Co powiedziałby moja babcia? (za: Borba 2016). Umiejętność krytycznego myślenia i podejmowania decyzji pozwala na uniknięcie wielu napięć i obciążeń, ale także konsekwencji nietrafnych wyborów życiowych. Zdolności te należałoby także ująć jako ważne dla obniżania poziomu stresu wśród dzieci i młodzieży. 
Ćwiczenia z zakresu zdolności przyjmowania cudzej perspektywy, czyli „stawania w cudzych butach", to kolejna poznawcza umiejętność empatycznego dziecka. Dzięki zdolności przyjmowania cudzej perspektywy łatwiej jest przezwyciężać egocentryzm i zrozumieć innych. Ta zdolność wpływa na lepsze, mniej stresujące relacje $\mathrm{z}$ otoczeniem oraz także na podejmowanie decyzji uwzględniających inny niż własny punkt widzenia. Umiejętność ta jest także wskazywana jako kluczowa w rozwiązywaniu problemów, podejmowaniu współpracy i rozwiązywaniu konfliktów (Davis 1996).

Empatyczne dzieci posiadają zatem większą samoświadomość i samokontrolę, przez co wykazują większą odporność psychiczną, łatwiej radzą sobie z porażkami i problemami oraz wykazują skuteczne strategie radzenia sobie ze stresem. Wszystkie te czynniki można uznać za indywidualny potencjał, wpływający na zdrowy styl życia oraz obniżający ryzyko negatywnych skutków obciążenia stresem, a co za tym idzie, zagrożenia chorobami cywilizacyjnymi.

\section{Czynniki środowiskowe wpływające na poziom stresu oraz sposoby redukcji jego negatywnych skutków}

Dzięki empatii jesteśmy w stanie szybko i skutecznie reagować na sygnały wysyłane przez inne osoby. Dzięki takiej umiejętności empatyczne osoby potrafią budować satysfakcjonujące i zdrowe relacje z otoczeniem, oparte na szybkiej i sprawnej komunikacji. Empatia służy zatem tworzeniu wspierającego środowiska - udanych związków i relacji grupowych, co zaś przekłada się - także w przypadku dzieci na zdrowsze życie i mniejsze obciążenie stresem (Czerniak i in. 2012). Poprzez proces wyrażania emocji dostarczamy innym osobom informacji na temat tego, co przeżywamy, ale także wpływamy na ich zachowanie (Aronson 1995). Taki procesualny charakter empatii umożliwia szybkie „dostrojenie się” oraz wzajemne odpowiadanie na sygnalizowane potrzeby. Empatia jest zatem procesem służącym odpowiedniemu, szybkiemu reagowaniu na potrzeby innych osób (por. Lawrence i in. 2004; Eisenberg 2005; Altmann, Roth 2013).

Wiele badań wskazuje na fakt, że wysoki poziom empatii łączy się z podejmowaniem działań na rzecz innych (Batson, Shaw 1991; Hoffman 2005; Eisenberg i in. 2010). $Z$ drugiej strony, osoby o obniżonym poziomie empatii są bardziej skłonne do zachowań agresywnych i antyspołecznych (Hoffman 2005; Baron-Cohen 2014). Empatia może być zatem rozumiana jako ważny zasób społeczny.

Nie dziwi zatem fakt, że rozwijanie empatii jest bardzo pożądane - zwłaszcza jako element tworzenia zdrowego środowiska, wspierającego dzieci w trudnych chwilach i wspomagającego je w radzeniu sobie z trudnościami. Rozwijając, stymulując empatię u dzieci, wychowujemy je na osoby wrażliwe, chętnie pomagające innym, umiejące współpracować, tworzyć udane relacje, związki (Howe 2013).

Empatyczne dzieci dają sobie nawzajem więcej wsparcia i pomagają sobie w trudnych chwilach - okazują zainteresowanie, starają się pomóc i wybierają 
bardziej adekwatne formy pomocy. Dodatkowo koncentrując się na komunikacyjnym charakterze empatii, uczy się dzieci jej komunikowania, formułowania wspierających komunikatów. Dzięki temu dzieci potrafią słuchać siebie empatycznie i reagować na trudne sytuacje, udzielając innym wsparcia emocjonalnego. Empatyczne dzieci nie tylko potrafią mówić o swoich emocjach, uwalniając napięcie, ale także przyjmować cudze emocje i reagować na nie we wspierający osobę sposób (Howe 2013).

Dla utworzenia empatycznych grup i społeczności konieczne jest powstanie odpowiednich procedur oraz norm sprzyjających empatii. Odkrycia psychologii społecznej pokazały, jak silny wpływ na zachowania mogą mieć czynniki sytuacyjne, klasyczny eksperyment więzienny Zimbardo (2009) wykazał, że czynniki sytuacyjne mogą niemal całkowicie przejąć kontrolę nad ludzkim zachowaniem, powodując, że zwykli ludzie mogą wycofać swoją empatię i krzywdzić innych tylko dlatego, że znaleźli się w silnie determinującej takie zachowania sytuacji. Przekładając tę wiedzę na sytuacje szkolne, znaczny wpływ na poziom empatii mają warunki panujące w tym miejscu, tworzące klimat szkoły (Surzykiewicz 2008; Przewłocka 2015). Chcąc rozwijać empatię u dzieci, konieczne jest zatem oddziaływanie całościowe: na grupę, społeczność szkolną, a nawet na całe społeczeństwo. Normy związane z odpowiedzialnością za siebie i innych, zaufaniem i troską, przyzwoleniem na odczuwanie i okazywanie uczuć wiążą się znacząco z poziomem empatii u poszczególnych jednostek. Normy takie sprzyjają także redukcji poziomu stresu wśród dzieci, tworząc bardziej przyjazne im i wspierające je instytucje i społeczności. Przykładowo, wspierająca i dobrze zintegrowana grupa może łatwiej radzić sobie z problemami, np. konfliktami, i rozwiązywać je w bardziej korzystny sposób. Tworzenie w szkołach różnych form sprawiedliwości naprawczej, w których każde dziecko ma możliwość powiedzenia o problemach, swoich uczuciach oraz proponowanych rozwiązaniach, czy też szkolne programy mediacji rówieśniczych, są doskonałym przykładem działań wspierających w sposób instytucjonalny rozwiązywanie problemów na drodze dialogu i empatii. Silna, wspierająca grupa jest także wymieniana jako ważny czynnik zdrowia psychicznego dzieci i młodzieży dojrzewającej (Czerwiak i in. 2012). Dzięki tworzeniu na terenie szkoły procedur oraz instytucji zapewniających dzieciom możliwość wypowiedzenia się w swojej sprawie, zredukowania emocji oraz wspólnego odpowiedzialnego podejmowania decyzji (brania odpowiedzialności za własne czyny) dzieci mogą rozwiązywać konflikty szybciej i skuteczniej, a osiągane porozumienia są trwalsze (Borba 2016).

Tworzenie przyjaznego otoczenia dziecka to także kwestia ograniczania zjawiska przemocy rówieśniczej. Doświadczanie przemocy przez dzieci i młodzież jest jednym z poważnych zagrożeń dla ich zdrowia, a nawet życia. Doświadczanie przemocy może mieć poważne negatywne konsekwencje zdrowotne, bez względu na fakt, czy dziecko doświadcza jej w środowisku domowym czy rówieśniczym (Finkelhor 2008). Do konsekwencji tych można zaliczyć: zaburzenia nastroju, niepokój, wycofanie, samotność, dolegliwości somatyczne, a nawet niedostosowanie społeczne 
(Rijntes i in. 2010). Jak wynika z analizy Fundacji Dzieci Niczyje (Włodarczyk, 2013), na przemoc rówieśniczą szczególnie narażeni są nastolatkowie, a zjawisko to jest wśród nich powszechne. Ponad 59 proc. nastolatków doświadczyło przemocy rówieśniczej, z czego 41 proc. - przemocy fizycznej, 25 proc. - psychicznej.

Wobec tak powszechnego i groźnego zjawiska konieczne jest podejmowanie działań profilaktycznych. Różnego rodzaju programy o potwierdzonej skuteczności posiadają w sobie często komponent rozwijania empatii, jako kluczowego mechanizmu hamującego agresywne zachowania.

Badania psychologów i ewolucjonistów wskazują na fakt, że empatia pojawiła się w toku ewolucji m.in. po to, aby hamować wrogie zachowania w stosunku do bliskich osób (de Waal 2005). Dzięki empatycznym procesom możemy powstrzymać się od wyrządzenia komuś szkody - np. gdy widzimy cudzy ból. Na bazie empatycznych reakcji pojawiają się reakcje poznawczo-emocjonalne, sprawiające, że zaprzestajemy krzywdzenia (np. czując czyjś ból i cierpienie przestajemy kogoś krzywdzić). Empatia to także umiejętność fantazjowania, wyobrażania sobie, jak nasze przyszłe zachowania zostaną odebrane przez inną osobę. Dzięki empatii możemy analizować i podejmować świadome decyzje, które pozwolą żyć w zgodzie z innymi, bez ranienia ich. Wnikliwe analizy dotyczące osób stosujących przemoc wskazują na to, że nie potrafią one oceniać trafnie konsekwencji swoich działań, lub nie odbierają i nie interpretują poprawnie sygnałów emocjonalnych wysyłanych przez otaczające je osoby. Metody terapeutyczne, opierające się w dużej mierze na treningu empatii, dają wymierne efekty, a nowoczesne metody obrazowania pracy mózgu pokazują, że nawet psychopaci, przestępcy, patologiczni sprawcy przemocy mogą „trenować własne mózgi” w każdym wieku. Prowadzone przez Daniela Reisela badania nad przestępcami (2015) pokazują, że w wyniku działań naprawczych (np. spotkania z ofiarami przestępstw) dokonują się zmiany neurologiczne w obrębie struktur tworzących tzw. obwód empatii, zwłaszcza w ciele migdałowatym. Osoby pozbawione zdolności współodczuwania mogą pod wpływem świadomych oddziaływań zmieniać własne mózgi i stawać się bardziej wrażliwymi osobami. Pod wpływem prowadzonego programu spotkań pomiędzy sprawcami przestępstw a osobami pokrzywdzonymi zanotowano istotne zmiany zarówno w wielkości, jak i aktywności struktur w obrębie ciała migdałowatego sprawców. Podobne wyniki u osób z zaburzeniami empatii przedstawiał Baron-Cohen (2014), badając nie tylko mózgi sprawców przemocy, ale także osób ze spektrum autyzmu. Neurobiologiczne dowody wskazują na skuteczność treningów empatii, jako skutecznego narzędzia terapeutycznego i profilaktycznego.

$\mathrm{Z}$ tego powodu elementy treningu empatii od lat włączane są do programów profilaktycznych i naprawczych realizowanych w szkołach. Przykładem sprawdzonych oddziaływań mogą być programy: przeciwdziałania przemocy (Fesbach 1979; Feshbach, Feshbach 1982), McMahona i Washburna (2003) czy Jagersa (2008). Także na gruncie polskim istnieje wiele programów niosących w sobie istotny element rozwijania empatii. Istnieją wyniki ewaluacji programów PATH oraz Treningu 
Zastępowania Agresji, Golden Five, mających duży wpływ na rozwijanie empatii oraz skutecznie zmniejszające poziom agresji wśród młodzieży.

\section{Podsumowanie}

Rozwijanie empatii traktowane w sposób wielowymiarowy, jako sposób wychowania obejmujący szereg oddziaływań, nie tylko na jednostkę, lecz także na społeczność, można potraktować jako działanie przynoszące szereg prozdrowotnych korzyści. Empatyczne dzieci, tworzące empatyczne społeczności, lepiej radzą sobie z wieloma wyzwaniami współczesnego świata w ponowoczesności, pełnej zagrożeń cywilizacyjnych. Rozwijanie empatii pozwala bowiem na wykształcenie lepszych mechanizmów samoregulacji, samoświadomości i samokontroli - prowadzi do zwiększenia odporności psychicznej, lepszego funkcjonowania psychospołecznego. Konsekwencją może być zdrowszy styl życia, mniejsze obciążenie stresem i wykształcenie zdrowych i skutecznych strategii radzenia sobie z nim. Empatyczna grupa (społeczność, a nawet społeczeństwo) tworzy ponadto zdrowsze, bardziej wspierające, kooperatywne środowisko, niosące mniej zagrożeń związanych z agresją, przemocą i chorobami cywilizacyjnymi. Wychowanie do empatii powinno zatem być ważnym elementem edukacji, na stałe zakorzenionym w praktykach edukacyjnych na terenie szkół i placówek wychowawczych.

\section{Bibliografia}

Altmann T., Roth M. (2013). The evolution of empathy: from single components to process models. W: Mohiyeddini C., Eysenck M., Bauer S. (red.). Handbook of Psychology of Emotions. Nowy Jork: Nova Science Publishers, s. 171-188.

Aronson E. (1995). Człowiek istota społeczna. Warszawa: PWN.

Baron-Cohen S. (2014). Teoria zła. O empatii i genezie okrucieństwa. Sopot: Smak Słowa.

Batson C. D., Shaw L. L. (1991). Evidence for altruism: toward a pluralism of prosocial motives. „Psychological Inquiry”, 2 (2), s. 107-122.

Borba M. (2016). Unselfie: Why Empathetic Kids Succeed in Our All-about-me World. Simon and Schuster.

Bowlby J. (2007). Przywiązanie. Warszawa: Wydawnictwo Naukowe PWN.

Cohen D., Strayer J. (1996). Empathy in conduct-disordered and comparison youth. „Developmental Psychology”, 32 (6), s. 988-998.

Czerwiak A., Czerwiak G., Kaczmarczyk M. (2012). Styl życia gimnazjalistów. „Stud. Med.” 26, 2, s. 61-68.

Davis M. H. (1983). Measuring individual differences in empathy: Evidence for a multidimensional approach. „Journal of Personality and Social Psychology”, 44 (1), s. 113-126. 
Davis M. H. (1999). Empatia. O umiejętności współodczuwania. Gdańsk: Gdańskie Wydawnictwo Psychologiczne.

De Waal F. (2005). The evolution of empathy, dostępny na: http://greatergood.berkeley.edu/article/item/the_evolution_of_empathy (otwarty: 27.01.2016).

Dziubak M., Dziedzic, Mierzwa M. A. (2011). Wiedza licealistów o wpływie stylu życia na występowanie chorób układu krążenia i chorób nowotworowych a ich zachowania zdrowotne. "Przegląd Medyczny Uniwersytetu Rzeszowskiego i Narodowego Instytutu Leków w Warszawie”, 2, s. 235-237.

Eienberg N., Eggum N. D., Di Giunta L. (2010). Empathy-related responding. Associations with prosocial behavior, aggression, and intergroup relations, „Social Issues Policy Review", 4 (1), s. 143-180.

Eisenberg N. (2005). Empatia i współczucie. W: Lewis M., Haviland-Jones J. M., Psychologia emocji. Gdańsk: Gdańskie Wydawnictwo Psychologiczne.

Enz S., Zoll, C., Spielhagen C., Diruf M. (2009). Concepts and evaluation of psychological models of empathy. AAMAS.

Feshbach N. D. (1979). Empathy training: a field study in affective education. W: Feshbach S., Fraczek A. (red.). Aggression and behavior change: biological and social processes. Nowy Jork: Praeger.

Feshbach N. D., Feshbach S. (1982). Empathy training and the regulation of aggression: potentialities and limitations. „Academic Psychology Bulletin”, 4 (3), s. 399-413.

Finkelhor D. (2008). Childhood Victmization. Violence, Crime, and Abuse in the Lives of Young People. New York: Oxford University Press.

Goleman D. (2007). Inteligencja emocjonalna. Warszawa: Wydawnictwo Media Rodzina.

Hoffman M. L. (2006). Empatia i rozwój moralny. Gdańsk: Gdańskie Wydawnictwo Pedagogiczne.

Howe D. (2013). Empatia. Co to jest i dlaczego jest taka ważna. Warszawa: Oficyna Ingenium.

Jagers R. J., Morgan-Lopez A. A., Howard T. L., Browne D. C., Flay B. R. (2007). Mediators of the development and prevention of violent behavior. „Prevention Science", 8 (3), s. 171-179.

Kolarczyk E. B. (2015) Zachowania zdrowotne młodzieży gimnazjalnej i ponadgimnazjalnej. „Prace poglądowe. Piel. Zdr. Publ. H.” 5, 3, 3. Wrocławski Uniwersytet Medyczny. Wrocław, s. 305-310.

Lawrence E. J., Shaw P., Baker D., Baron-Cohen S., (2004). Measuring empathy: reliability and validity of the Empathy Quotient. "Psychological Medicine”, 34 (5), s. 911-919.

Lehrer J. (2009) „Don't!”. „The New Yorker”, May 18.

Lemerise E. A., Arsenio W. F. (2000). An integrated model of emotion processes and cognition in social information processing. „Child Development”, 71 (1), s. 107-118.

Lewicka A. (2006). Rozwijanie empatii u studentów pedagogiki specjalnej. Lublin: Wydawnictwo UMCS. 
Loewenstein G. (2005). Hot-cold empathy gaps and medical decision making. „Health Psychology", 24 (4S), s. 49-55.

McMahon S. D., Washburn, J. J. (2003). Violence prevention: an evaluation of program effects with urban African American students. "Journal of Primary Prevention", 24 (1), s. 43-62.

Przewłocka J. (2015). Klimat szkoły i jego znaczenie dla funkcjonowania uczniów w szkole. Raport o stanie badań. Warszawa: Instytut Badań Edukacyjnych.

Reijntjes A., Kamphuis J. H., Prinzie P., Telch M. T. (2010). Peer victimization and internalizing problems in children: A meta-analysis of longitudinal studies. „Child Abuse \& Neglect", 34 (4), s. 244-252.

Reisel D. (2015). Towards a Neuroscience of Morality. The Psychology of Restorative Justice: Managing the Power Within.

Rizolatti G. (1996). Premotor cortex and the recognition of motor actions. „Cognitive Brain Research", 3, s. 131-141.

Rizzolatti G., Fadiga L., Gallese V., Fogassi L. (1996). Premotor cortex and the recognition of motor actions. „Cognitive Brain Research”, 3 (2), 131-141.

Siegel D. J. (2007). The mindful brain: Reflection and attunement in the cultivation of well-being. New York: WW Norton \& Company.

Surzykiewicz J. (2008). Profilaktyczna pomoc wychowawcza szkole w zapobieganiu agresji: znaczenie kompetencji społecznych. W: Libiszowska-Żółtkowska M., Ostrowska K. (red.). Agresja w szkole. Diagnoza i profilaktyka. Warszawa: Wydawnictwo Difin.

Szymańska J. (200o). Programy profilaktyczne. Podstawy profesjonalnej psychoprofilaktyki. Warszawa: Centrum Metodyczne Pomocy Psychologiczno-Pedagogicznej Ministerstwa Edukacji Narodowej.

Terrie E. Moffitt et al. (2011), A Gradient of Childhood Self-Control Predicts Health, Wealth, and Public Safety, „Proceedings of the National Academy of Sciences”, 108, nr 7 (2011), s. 2693-2698.

Wilczek-Rużyczka E. (2002). Empatia i jej rozwój u osób pomagających. Kraków: Wydawnictwo Uniwersytetu Jagiellońskiego.

Włodarczyk J. (2013). Przemoc rówieśnicza. Wyniki Ogólnopolskiej diagnozy problemu przemocy wobec dzieci. „Dziecko Krzywdzone. Teoria, badania, praktyka”, $12(3), 63-82$.

Zimbardo P. G. (2009). Efekt Lucyfera. Dlaczego dobrzy ludzie czynia zło? Warszawa: PWN.

Zoll C., Enz S. (2010). A questionnaire to assess affective and cognitive empathy in children. Bamberg: Otto-Friedrich-Universität Bamberg. 


\title{
UPBRINGING FOR EMPATHY AS A WAY OF REDUCING STRESS AND ITS HARMFUL EFFECTS
}

\begin{abstract}
The text presents an interdisciplinary take on upbringing for empathy, based on a signature theoretical model. Adopting a so understood definition of empathy results in universal and multilevel interactions aimed at children and youth. The effects of these actions bring various benefits on an intrapersonal and interpersonal level - including reducing stress levels in children and strengthening personal and social resources that contribute to improving strategies of coping with stress and its negative effects. Empathy is also a proven method of preventing peer violence - a problem that is still present in Polish schools and leads to numerous health damages.

Keywords: empathy, health, stress, emotional self-regulation, peer violence, children, youth.

Maciej Ciechomski - magister psychologii, doktor nauk społecznych w dyscyplinie pedagogika, zatrudniony na stanowisku adiunkta na Wydziale Nauk Pedagogicznych UKSW w Warszawie w Katedrze Psychologicznych Podstaw Pedagogiki. Specjalizuje się w psychologii wychowawczej, szczególnie w dziedzinie rozwijania empatii u dzieci, samoregulacji emocjonalnej. Pracuje także jako mediator (także jako mediator sądowy) oraz trener przy programach profilaktycznych oraz projektach rozwijających umiejętności psychologiczne i społeczne u dzieci i dorosłych. Adres e-mailowy: m.ciechomski@uksw.edu.pl.
\end{abstract}

